\title{
A New Synthesis of Benzonitriles Catalyzed by Microwave Irradiation
}

\author{
Yara J. K. Araujo (PG); Isac G. Rosset (PG); André L. M. Porto* (PQ) \\ Instituto de Química de São Carlos, Universidade de São Paulo, Av. Trabalhador São-Carlense, 400, CEP \\ 13560-970, São Carlos-SP.
}

\section{Email:yarajaque@hotmail.com; almporto@iqsc.usp.br}

Keywords: Amides, microwave, nitriles.

\section{INTRODUCTION}

Aromatic and aliphatic nitriles are common intermediates in the industrial production of polyamides, pharmaceuticals, agrochemicals, dyes, pigments, and fine chemicals ${ }^{1}$. Moreover, in organic synthesis the nitrile group serves as an important starting material for various transformations into other functional groups, such as amines, aldehydes, ketones, heterocycles ${ }^{2}$. In this work a new way to synthesize benzonitriles is reported.

\section{RESULTS AND DISCUSSION}

The amides 5-8 were easily synthesized using a simple procedure already described in a literature employing THF dry and ammonium hydroxide according the literature from respective ketones (14) $)^{3}$ (Scheme 1).

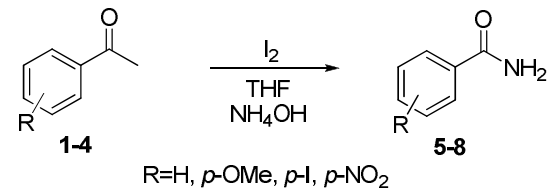

Scheme1. Synthesis of the amides 5-8 from ketones 1-4.

The amides 9-12 were obtained commercially and used for the next reactions. The imides 13-20 and nitriles 21-28 were obtained by the reaction of the amides 5-12 with acetic anhydride in the microwave reactor at $140^{\circ} \mathrm{C}$ by $30 \mathrm{~min}$ (Scheme 2). In a two neck flask were added the respective amides 5-12 (100 mg) and acetic anhydride $(2 \mathrm{~mL})$ and subjected to microwave radiation for $30 \mathrm{~min}$ at $200 \mathrm{~W}$.

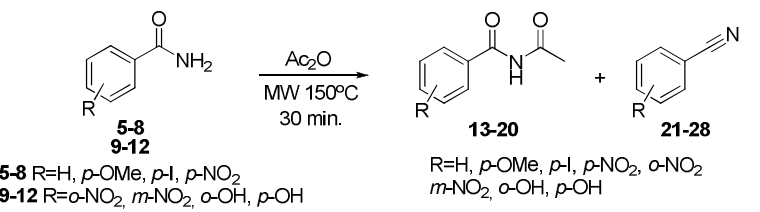

Scheme 2. Syntheses of imides 13-20 and nitriles 21-28 by microwave radiation.

A study the intention of observing group attached to the aromatic ring, as well as its position in the ring, as it can be observed in the table 1.
Table 1.Results obtained for the reaction of amides in the presence of acetic anhydride and MW.

\begin{tabular}{cccc}
\hline & Amides & Imides & Nitriles \\
Entry & $\mathbf{R}$ & \multicolumn{2}{c}{ Isolated Yields (\%) } \\
\hline Amides & $\mathrm{H}$ & 10 & 84 \\
5 & $p-\mathrm{OMe}$ & 4 & 7 \\
6 & $p-\mathrm{I}$ & 7 & 32 \\
7 & $p-\mathrm{NO}_{2}$ & 30 & 26 \\
8 & $o-\mathrm{NO}_{2}$ & 11 & 26 \\
9 & $m-\mathrm{NO}_{2}$ & - & 35 \\
10 & $o-\mathrm{OH}_{1}$ & - & 42 \\
11 & $p-\mathrm{OH}$ & 40 & 5 \\
12 & & &
\end{tabular}

It was obtained both the products, imides and nitriles with different yields. For the amide 12, was obtained the product 20 (Scheme 3).

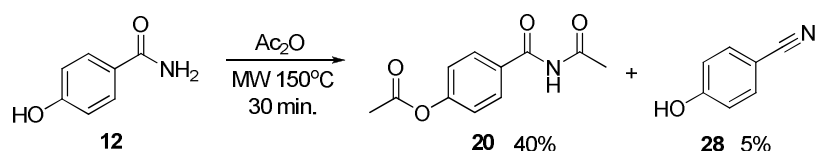

Scheme 3. Synthesis of the ester imide and nitrile.

The formation mechanism of nitrile is similar to that suggested by Narsaiah and Nagaiah ${ }^{4}$.

\section{CONCLUSION}

The reactions for the preparation of the amides provided good yields and these amides were transformed in a respective imides and nitriles by microwave irradiation in a short time and with different yields. This methodology showed to be efficient for the preparation of these compounds classes.

\section{ACKNOWLEDGEMENTS}

The authors thank FAPESP, CAPES and CNPq for financial support.

\section{REFERENCES}

${ }^{1}$ (a) R. C. Larock, Comprehensive Organic Transformations, $\mathrm{VCH}, \mathrm{New}$ York, 1989, p 819; (b) C. Grundmann, in Houben-Weyl:Methoden der organischen Chemie, ed. J. Falbe, Georg ThiemeVerlag, Stuttgart, 4th edn, 1985, vol. E5, p 1313.

${ }^{2}$ S. Zhou, D. Addis, S. Das, K. Junge and M. Beller, Chem. Commun., 2009, 4883-4885.

${ }^{3}$ N. A. Angeles, F. Villavicencio, C. Guadarrama, D. Corona and E.

Cuevas-Yañez, J. Braz. Chem. Soc., 2010, Vol. 21, No. 5, 905-908.

${ }^{4}$ A.V. Narsaih and K. Nagaiah, Adv. Synth. Catal., 2004, 346, 1271-1274.

$14^{\text {th }}$ Brazilian Meeting on Organic Synthesis - $14^{\text {th }}$ BMOS - September 01-05, 2011-Brasilia, Brazil 